\title{
Candida caseinolytica sp. nov., a New Species of Yeast Occurring in Necrotic Tissue of Opuntia and Stenocereus Species in the Southwestern United States and Baja California, Mexico
}

\author{
HERMAN J. PHAFF, ${ }^{1 *}$ WILLIAM T. STARMER, ${ }^{2}$ MARC-ANDRE LACHANCE, ${ }^{3}$ AND PHILIP F. GANTER ${ }^{4}$ \\ Department of Food Science and Technology, University of California, Davis, California 95616 ${ }^{1}$; Department of Biology, \\ Syracuse University, Syracuse, New York $13210^{2}$; Department of Plant Sciences, University of Western Ontario, London, \\ Ontario, Canada N6A SB7 $7^{3}$ and Department of Biology, Tennessee State University, Nashville, Tennessee $37204^{4}$
}

\begin{abstract}
We describe Candida caseinolytica, a new yeast species which occurs in rotting tissues of opuntias and other cacti in the North American Sonoran Desert and a few other localities. This small-celled, slowly growing yeast does not ferment any sugar and assimilates a limited number of carbon compounds, including 2- and 5-ketogluconic acids. It exhibits strong extracellular proteolytic activity on casein at pH 6.5, but gelatin is not hydrolyzed or is only weakly hydrolyzed by a few strains. The type strain of $C$. caseinolytica is strain UCD-FST 83-438.3 (= ATCC 90546 = CBS 7781).
\end{abstract}

During extensive surveys of more than 5,000 isolates in the yeast biota found in rotting tissues of various cactus species obtained from a wide variety of geographic areas $(2,12,15)$, we isolated a small number of strains of a unique, slowly growing, small-celled yeast species; these strains were isolated mainly from various Opuntia and Stenocereus species (Table 1) growing in a rather restricted region of the North American Sonoran Desert and a few other localities. The colonies of this yeast species were recognized on the isolation medium used ( $\mathrm{pH}$ ca. 3.8) by their small size, late appearance compared with other cactus-specific species, very glossy smooth surfaces, and white color. The unusually small budding cells occurred mainly as single cells and in pairs. Subsequent physiological tests showed that these strains exhibited an exceptionally strong ability to hydrolyze casein at $\mathrm{pH} 6.5$, a property that had not been observed previously in any of the other cactus-specific species described by us. As ascosporulation was not observed, the strains fit the description of the genus Candida sensu Yarrow and Meyer (17). A comparison of the phenotypic properties of this organism with the properties of other Candida species $(3,8)$ and a recent up-to-date key to species of the genus (7) revealed that the cactus isolates represent a new species, for which we propose the name Candida caseinolytica.

\section{MATERIALS AND METHODS}

Samples of rotting cactus tissues collected during 1981, 1983, 1984, 1985, 1986, 1987, and 1991 were obtained from host plants in the locations shown in Table 1 . The technique used for yeast isolation and purification has been described in detail previously by Starmer and Phaff (13).

The isolates were characterized phenotypically by methods currently used in yeast taxonomy (16), but additional carbon compounds were used in the assimilation tests. These additional carbon compounds included hexadecane, glucosamine, $N$-acetylglucosamine, methanol, 2-propanol, acetone, and ethyl acetate. 2-Propanol, acetone, and ethyl acetate were tested by adding each compound at a concentration of $1 \%$ ( $\mathrm{vol} / \mathrm{vol}$, based on medium volume) to the inverted cover of a flat-bottom glass petri dish after inoculation of the test cultures with a multipoint inoculator. The dishes were then sealed with

\footnotetext{
${ }^{*}$ Corresponding author. Phone: (916) 752-1238. Fax: (916) 752-
}

Parafilm M (American Can Co., Greenwich, Conn.) and incubated upside down.

The medium used for the casein hydrolysis test, which is not a routine test in yeast taxonomy, was a slightly modified version of the medium used by Ahearn et al. (1). First, $1.5 \mathrm{~g}$ of beef extract (Difco), $2.5 \mathrm{~g}$ of Bacto Tryptone, $0.5 \mathrm{~g}$ of glucose, and $8.5 \mathrm{~g}$ of agar were added to $440 \mathrm{ml}$ of deionized water, and the preparation was autoclaved. Then $12 \mathrm{~g}$ of skim milk powder (Difco) was mixed with deionized water with a mortar and pestle, the volume was brought to $60 \mathrm{ml}$, and the preparation was autoclaved at $12 \mathrm{lb} / \mathrm{in}^{2}$ for $12 \mathrm{~min}$. The two solutions were cooled to about $50^{\circ} \mathrm{C}$ and mixed together thoroughly before the final preparation was poured into petri dishes. The final $\mathrm{pH}$ was 6.5 . The extent of clearing caused by casein hydrolysis was determined daily at $25^{\circ} \mathrm{C}$ for up to 1 week rather than 3 weeks, which was the time period used by Ahearn et al. (1).

Susceptibility to triterpene glycosides was tested at 25 and $37^{\circ} \mathrm{C}$ in $\mathrm{YM}$ agar plates containing $1 \%$ dried, powdered Stenocereus gummosus (agria) tissue, as described by Starmer et al. (11).

DNA was extracted, purified, and hybridized by the methods described by Price et al. (10), except that purified DNA was concentrated by electrophoresis in a concentrator (ISCO, Lincoln, Nebr.) and the reference DNA was labeled with ${ }^{125}$ I as described by Holzschu et al. (5). The $\mathrm{G}+\mathrm{C}$ contents of the nuclear DNAs were calculated from buoyant density values in cesium chloride gradients established in a Spinco model $\mathrm{E}$ analytical ultracentrifuge (10).

\section{RESULTS}

Latin diagnosis of Candida caseinolytica sp. nov. In YM (Difco) liquido post dies 5 ad $30^{\circ} \mathrm{C}$, cellulae ovoideae vel brevi-cylindricae, $1.3-2.5 \times 2.5-5.0 \mu \mathrm{m}$, singulae, binae vel catenis brevis; sedimentum; pellicula nulla. Cultura in agaro malti post dies 21 ad $25^{\circ} \mathrm{C}$ cana-cremea, butyrosa vel mollis, glabra, nitida, margine glabro.

In agaro farinae Zea mays post dies 10 pseudomycelium nullum.

Fermentatio glucosi nullum. Glucosum, galactosum, sorbosum (lente), trehalosum (lente), xylosum, ethanolum, glucono8-lactonum, gluconatum, 2-ketogluconatum, 5-ketogluconatum, acidum lacticum (lente), acidum succinicum (interdum exigue), ethyl acetas (exigue) assimilantur at non maltosum, 
TABLE 1. Geographic origins and host plants of C. caseinolytica strains

\begin{tabular}{|c|c|c|c|}
\hline Strain $^{a}$ & $\begin{array}{c}G+C \text { content } \\
(\mathrm{mol} \%)\end{array}$ & Host plant & Location \\
\hline UCD-FST 81-434.2 & 46.9 & Opuntia phaeacantha & Santa Rita Mountains, Arizona \\
\hline UCD-FST $81-467.2$ & 47.4 & O. phaeacantha & Rincon Mountains, Arizona \\
\hline UCD-FST $81-471.1$ & 46.7 & O. phaeacantha & Rincon Mountains, Arizona \\
\hline UCD-FST 81-472.3 & 46.8 & O. phaeacantha & Rincon Mountains, Arizona \\
\hline UCD-FST $83-416.4$ & & O. phaeacantha & Tucson Mountains, Arizona \\
\hline UCD-FST 83-426.4 & & O. phaeacantha & Tucson Mountains, Arizona \\
\hline W84-201.5 & & O. phaeacantha & Tucson Mountains, Arizona \\
\hline UCD-FST $85-833.2$ & & O. phaeacantha & Tucson Mountains, Arizona \\
\hline UCD-FST $85-833.2$ & & O. phaeacantha & Tucson Mountains, Arizona \\
\hline G91-628.3 & & O. phaeacantha & Tucson Mountains, Arizona \\
\hline G91-706.5 & & O. phaeacantha & Tucson Mountains, Arizona \\
\hline UCD-FST $83-438.3^{\mathrm{T}}$ & 46.9 & O. phaeacantha & Santa Rita Mountains, Arizona \\
\hline UCD-FST 83-444.3 & & O. phaeacantha & Along Highway 83, Arizona \\
\hline UCD-FST 81-494.4 & 47.3 & Opuntia ficus-indica & Tucson, Ariz. \\
\hline UCD-FST $81-522.2$ & 46.4 & O. ficus-indica & Tucson, Ariz. \\
\hline UCD-FST 81-665.2 & 46.5 & Opuntia lindheimeri & Ozona, Tex. ${ }^{b}$ \\
\hline S $83-44$ & & Stenocereus thurberi & Organ Pipe National Monument, Ariz. \\
\hline$\$ 83-56$ & & S. thurberi & Organ Pipe National Monument, Ariz. \\
\hline S83-64 & & S. thurberi & Organ Pipe National Monument, Ariz. \\
\hline S83-102 & & S. thurberi & Organ Pipe National Monument, Ariz. \\
\hline S83-114 & & S. thurberi & Organ Pipe National Monument, Ariz. \\
\hline G91-702.5 & & S. thurberi & Organ Pipe National Monument, Ariz. \\
\hline G91-706.5 & & S. thurberi & Organ Pipe National Monument, Ariz. \\
\hline G91-714.5 & & S. thurberi & Organ Pipe National Monument, Ariz. \\
\hline S86-455.4 & & Stenocereus gummosus & Punta Prieta, Baja California Norte, Mexico \\
\hline S86-457.4 & & S. gummosus & Punta Prieta, Baja California Norte, Mexico \\
\hline S86-470.4 & & S. gummosus & Punta Prieta, Baja California Norte, Mexico \\
\hline S86-486.4 & & S. gummosus & Punta Prieta, Baja California Norte, Mexico \\
\hline S $86-460.6$ & & Drosophila mojavensis & Punta Prieta, Baja California Norte, Mexico \\
\hline G91-613 & & S. gummosus & Santa Catarina, Baja California Norte, Mexico \\
\hline G91-617 & & Myrtillocactus cochal & Santa Catarina, Baja California Norte, Mexico \\
\hline G91-618.4 & & M. cochal & Santa Catarina, Baja California Norte, Mexico \\
\hline G91-625 & & Opuntia sp. & Santa Catarina, Baja California Norte, Mexico \\
\hline G91-506.2 & & Opuntia sp. & Encinada, Baja California Norte, Mexico \\
\hline G91-510.2 & & Opuntia sp. & Encinada, Baja California Norte, Mexico \\
\hline S87-477.3 & & Opuntia (Nopalea) sp. & Zanatepec, Chiapas, Mexico \\
\hline W87-2430.3 & & Opuntia megacantha & Maui Island, Hawaii \\
\hline W91-445.1 & & Opuntia boarensis & Santa Rosa, Tucuman, Argentina \\
\hline UCD-FST 91-476.1 & & Opuntia quimila & Termas, Tucuman, Argentina \\
\hline
\end{tabular}

${ }^{a}$ UCD-FST, Culture Collection of the Department of Food Science and Technology, University of California, Davis. Designations that begin with G were assigned by P. F. Ganter; designations that begin with S were assigned by W. T. Starmer; and designations that begin with W were assigned by M. A. Lachance.

${ }^{b}$ An additional eight undesignated strains were collected from Opuntia engelmannii by P. F. Ganter in Texas in the valley of the Rio Grande and the Chisos Mountains.

saccharosum, cellobiosum, lactosum, melibiosum, raffinosum, melezitosum, inulinum, amylum solubile, L-arabinosum, Darabinosum, D-ribosum, L-rhamnosum, glycerolum, i-erythritolum, ribitolum, galactitolum, D-manitolum, D-glucitolum, $\alpha$-methyl-D-glucosidum, salicinum, acidum citricum, meso-inositolum, methanolum, acetonum, 2-propanolum, $\mathrm{N}$-acetylglucosaminum, glucosaminum, nec hexadecanum.

Kalium nitricum, natrium nitrosum non assimilantur. Ethyl aminum, L-lysinum, et cadaverinum assimilantur. Ad crescentiam vitaminae additae necessariae sunt. Crescere potest in $42^{\circ} \mathrm{C}$, interdum in $45^{\circ} \mathrm{C}$. $\mathrm{G}+\mathrm{C}$ acidi deoxyribonucleati $46.4-$ $47.4 \mathrm{~mol} \%$ ( 8 stirpes). Habitatio in cacti tribus Opuntieae et sub-tribus Stenocereinae.

Typus: stirps UCD-FST 83-438.3 ex tabidosus sacculis cacti Opuntia phaeacantha isolata est. In collectione zymotica Centraalbureau voor Schimmelcultures, Dephi Batavorum sub no. CBS 7781 deposita est.

Description of the type strain of Candida caseinolytica sp. nov. Candida caseinolytica (ca.se.i.no.ly' ti.ca. L. fem. adj. caseinolytica, casein hydrolyzing, referring to the pronounced ability of the organism to hydrolyze casein). In YM (Difco) liquid medium after 5 days at $30^{\circ} \mathrm{C}$ the cells are ovoidal to short cylindroidal ( 1.3 to 2.5 by 2.5 to $5.0 \mu \mathrm{m}$ ) and occur singly, in pairs, or in very short chains. A small amount of sediment develops after about 10 days; a pellicle or ring is not present. On YM agar the cells are similar, but occur only singly or in pairs; budding occurs mainly on the shoulders of the short cylindrical cells (Fig. 1). Streak cultures on malt agar after 3 weeks at $25^{\circ} \mathrm{C}$ are cream colored to greyish, convex with little spreading, smooth, glistening, and butyrous to pasty, and the periphery is entire.

In Dalmau plate cultures on cornmeal agar after 10 days, no pseudomycelium or true mycelium is produced.

Ascospore formation does not occur on various sporulation media. Mixing of strains in all possible combinations produces no evidence of a conjugation tube or zygote formation.

Does not ferment glucose.

Assimilates the following carbon compounds: glucose, Dgalactose, L-sorbose (latently), trehalose (latently), D-xylose, ethanol, glucono- $\delta$-lactone, gluconate, 2-ketogluconate, 5-ke- 


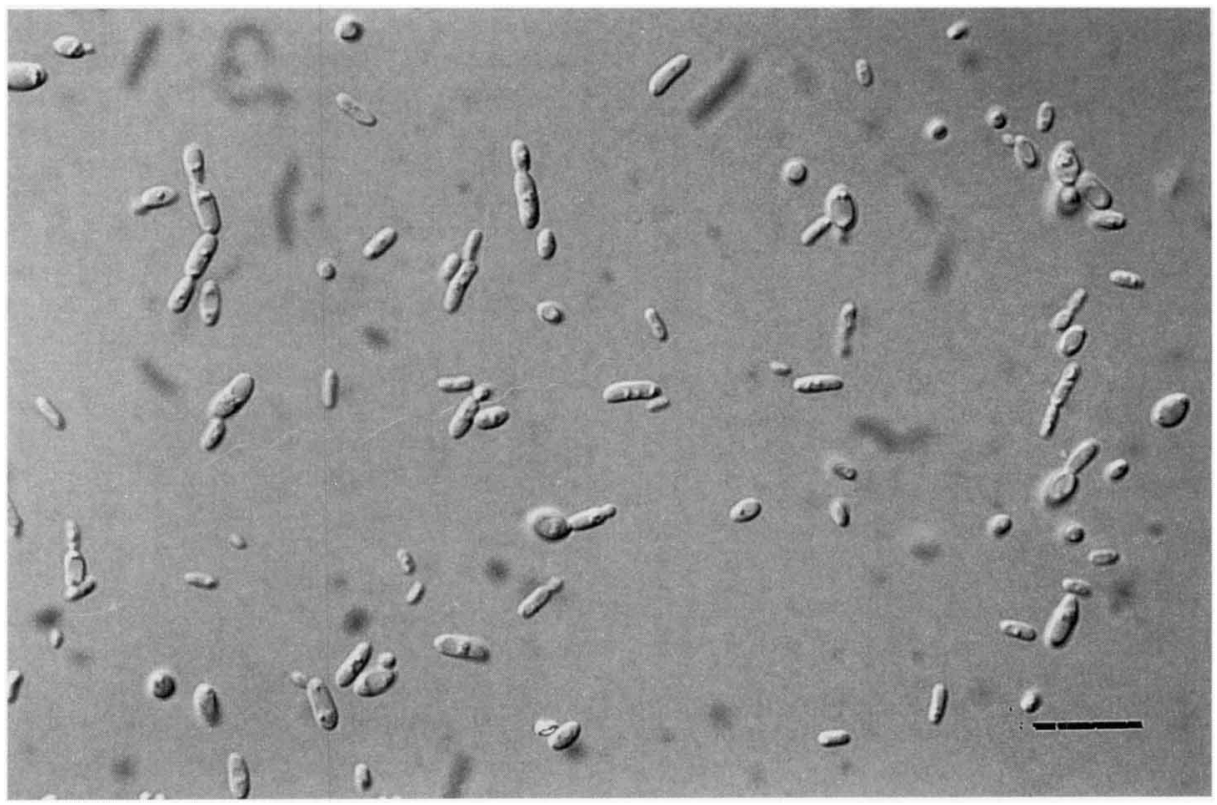

FIG. 1. Vegetative cells of $C$. caseinolytica grown for 3 days on $\mathrm{YM}$ agar medium at $25^{\circ} \mathrm{C}$. Bar $=10 \mu \mathrm{m}$.

togluconate, DL-lactate (latently), succinate, and ethyl acetate (weakly). Does not assimilate maltose, sucrose, cellobiose, lactose, melibiose, raffinose, melezitose, inulin, soluble starch, L-arabinose, D-arabinose, D-ribose, L-rhamnose, glycerol, ierythritol, ribitol, galactitol, D-mannitol, D-glucitol, $\alpha$-methylD-glucoside, salicin, citric acid, meso-inositol, methanol, acetone, 2-propanol, $\mathrm{N}$-acetylglucosamine, glucosamine, and hexadecane.

$\mathrm{KNO}_{3}$ and $\mathrm{NaNO}_{2}$ are not utilized as sole sources of nitrogen; ethyl amine, cadaverine, and L-lysine are utilized.

Grows in amino acid-free medium.

Does not grow in vitamin-free medium.

Growth in the presence of triterpene glycosides is moderate at $25^{\circ} \mathrm{C}$ and good at $37^{\circ} \mathrm{C}$.

Grows in the presence of $100 \mu \mathrm{g}$ of cycloheximide per $\mathrm{ml}$.

Growth on YM agar containing $5 \% \mathrm{NaCl}$ is moderate. Does not grow on $\mathrm{YM}$ agar containing $7.5 \% \mathrm{NaCl}$.

Does not grow in the presence of $50 \%$ glucose.

Casein hydrolysis is strongly positive at $\mathrm{pH} 6.5$ to 7.0 (Fig. 2).

Does not hydrolyze gelatin.

Lipolytic activity is weak.

Does not produce urease activity.

Grows at 42 and $45^{\circ} \mathrm{C}$.

The Diazonium Blue $\mathrm{B}$ reaction is negative.

Habitat: necrotic tissues of various cactus species in various locations (Table 1). The type strain is UCD-FST 83-438.3, which was isolated from Opuntia phaeacantha in the Santa Rita Mountains of Arizona; this strain has been deposited in the American Type Culture Collection as strain ATCC 90546 and in the Centraalbureau voor Schimmelcultures, Delft, The Netherlands, as strain CBS 7781.

Some strains differ from the type strain in the following assimilation characteristics: strains UCD-FST 81-444.3 and UCD-FST 91-476.1 do not assimilate D-xylose; strains UCDFST 81-444.3 and UCD-FST 81-467.2 do not assimilate gluconate and grow weakly on glucono- $\delta$-lactone; and strains UCD-FST 83-416.4 and UCD-FST 83-426.4 grow weakly on gluconate and glucono- $\delta$-lactone. However, all of these strains grow well on 2- and 5-ketogluconates. Assimilation of L- sorbose varies from latent to negative, and the ability to grow at 42 and $45^{\circ} \mathrm{C}$ also varies among the strains. A few strains hydrolyze gelatin weakly, and some lack lipolytic activity.

To verify the genetic homogeneity of the $C$. caseinolytica

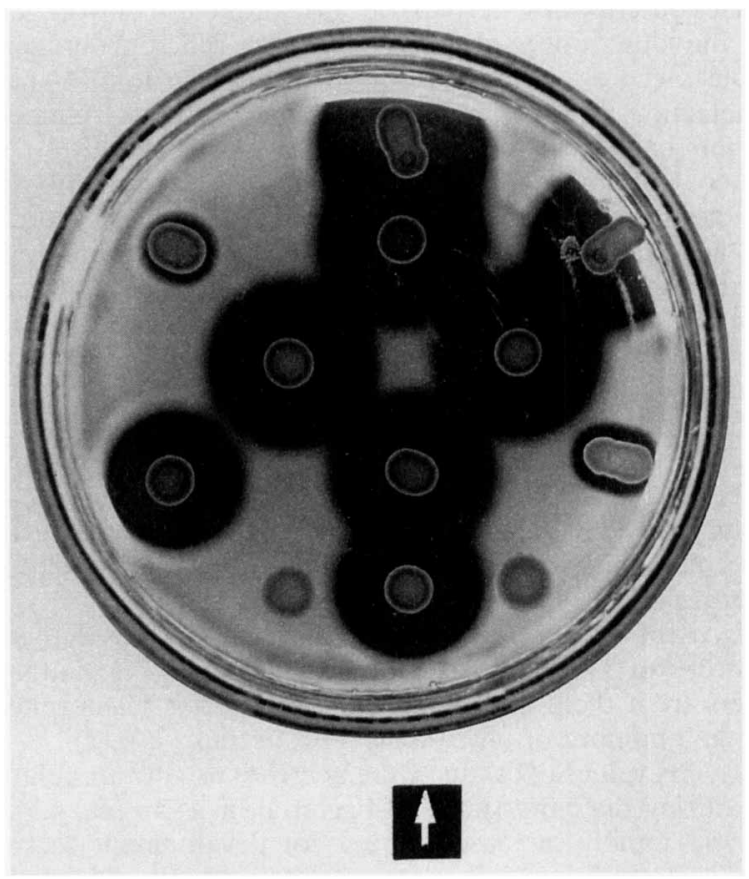

FIG. 2. C. caseinolytica strains and two control cactophilic yeast species on casein test medium after 4 days at $25^{\circ} \mathrm{C}$. The inocula were grown on YM agar. The following strains were used (counterclockwise from the arrow in the outer and inner circles): UCD-FST 81-472.3, Pichia cactophila, UCD-FST 83-426.4, UCD-FST 83-438.3 $3^{\mathrm{T}}$, UCDFST 81-434.2, UCD-FST 81-467.2, UCD-FST 81-471.1, Candida sonorensis, UCD-FST 81-494.4, UCD-FST 81-522.2, UCD-FST 81-665.2, and UCD-FST $85-833.2$ 
TABLE 2. Reannealing between labeled DNA from $C$. caseinolytica UCD-FST $83-438.3^{\mathrm{T}}$ and unlabeled DNAs from three yeast strains and unlabeled calf thymus control DNA ${ }^{a}$

\begin{tabular}{|c|c|}
\hline Source of unlabeled DNA & $\begin{array}{l}\text { Relative } \% \text { of bind- } \\
\text { ing with labeled } \\
\text { C. caseinolytica } \\
\text { UCD-FST } \\
83-438.3^{\mathrm{T}} \text { DNA }^{b}\end{array}$ \\
\hline \multicolumn{2}{|l|}{ C. caseinolytica strains } \\
\hline UCD-FST $83-438.3^{\mathrm{T}}$ & 100.0 \\
\hline UCD-FST $81-472.3 \ldots$ & 97.1 \\
\hline UCD-FST $81-665.2 \ldots \ldots$. & 91.4 \\
\hline 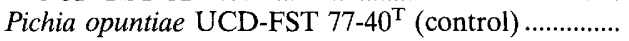 & 0.0 \\
\hline Calf thymus (control) & 0.5 \\
\hline
\end{tabular}

${ }^{a}$ See Table 1 for the origins of the three $C$. caseinolytica strains. Pichia opuntiae UCD-FST $77-40^{\mathrm{T}}$ was isolated from Opuntia stricta in Australia (2)

$b^{125} \mathrm{I}$-labeled DNA $(0.2 \mu \mathrm{g})$ and unlabeled DNA $(200 \mu \mathrm{g})$ were incubated at $65.7^{\circ} \mathrm{C}$ for $25 \mathrm{~h}$ in $0.5 \mathrm{mI}$ of $280 \mathrm{mM}$ phosphate buffer $(\mathrm{pH} 6.8)$. The values are the averages of the values from three determinations and were corrected for zero-time binding and for self-renaturation (10).

strains, a DNA hybridization experiment was performed with three strains isolated from three different host plants from different geographic locations. Table 2 shows that the levels of DNA complementarity among these strains were more than $90 \%$.

\section{DISCUSSION}

Strong extracellular proteolytic activity is relatively rare in yeasts and is most often but not exclusively observed in basidiomycetous species $(1,9)$. Historically, gelatin hydrolysis (liquefaction) was the parameter most commonly used in species descriptions, perhaps because of the use of wort gelatin for the description of giant-colony morphology in genetic studies, where a positive reaction resulted in total or partial liquefaction of the medium. More recently, a number of authors have used casein or albumin as a substrate to detect proteolytic activity $(1,9)$. Several species were found to exhibit significant activity against these proteins, although there was not necessarily a positive correlation between proteolysis of casein and proteolysis of gelatin (1), as is the case for most strains of $C$. caseinolytica. Some reports lack specific information concerning whether proteolytic activity is due to acid, neutral, or alkaline proteases.

Production of extracellular proteolytic enzymes is rarely used for taxonomic purposes. van der Walt and Yarrow (16) stated that since so few yeasts exhibit significant extracellular proteolytic activity against gelatin, only in cases where rapid and complete liquefaction is observed in about 1 week might this property be useful as a confirmatory test.

C. caseinolytica is the only cactus-specific species that exhibits strong extracellular caseinolytic activity (Fig. 1), and it also differs from them and other Candida species in morphology and in a number of physiological properties $(3,6,8)$.

The $\mathrm{pH}$ values of cactus tissue necroses usually are relatively low during the early stages of bacterial invasion (ca. 4.5 ), but the $\mathrm{pH}$ rapidly increases during rot development to values ranging from 7.5 to 8.5 , values at which the yeast protease is active. $C$. caseinolytica in developing necroses may gain a competitive advantage by having proteolytic ability.

It is interesting that $C$. caseinolytica appears to be geographically limited; this species has never been isolated in the Caribbean area or Australia $(12,2)$, even though we have analyzed numerous opuntia rots obtained from these areas. Although Opuntia species appear to be the most common host plants (Table 1), C. caseinolytica has also been isolated from members of the columnar cactus genera Stenocereus and Myrtillocactus, which are members of the subtribe Stenocereinae that contain high levels of triterpene glysosides, compounds that are inhibitory to a number of cactus-specific yeast species (11). C. caseinolytica is moderately resistant to triterpene glycosides and can therefore grow in necrotic tissues of these cacti. Fogleman and Starmer (4) reported isolating five strains from Stenocereus thurberi (organ-pipe cactus) in three locations sympatric with the opuntia host plants of $C$. caseinolytica in Arizona. Ganter isolated three additional strains in 1991 from $S$. thurberi in the same areas, while in 1986 and 1991 Starmer and Ganter recovered five strains from Stenocereus gummosus (agria) and two strains from Myrtillocactus cochal in Baja California Norte, Mexico. In each of the Mexican locations, Opuntia species also yielded $C$. caseinolytica. The remaining question is the primary habitat of the new species. We are inclined to consider Opuntia necroses the primary habitat, because numerous samples from organ-pipe and agria cacti in areas where opuntias are rare or nonexistent (15) did not yield this species. Moreover, the fact that one strain of $C$. caseinolytica was isolated in Texas and two strains were isolated from Opuntia spp. in Argentina (Table 1), where organ-pipe and agria cacti do not occur, supports this view. In locations where Opuntia species occur together with members of the genus Stenocereus, the yeast can be transmitted by various insects that feed on both types of rot (14). Opuntia spp. are not native to Hawaii, and their introduction from the Americas may explain the isolation of a single strain of C. caseinolytica on the island of Maui (Table 1).

\section{ACKNOWLEDGMENTS}

This work was supported by grants DEB 81-08679 and DEB 91-08898 from the National Science Foundation to W.T.S. and H.J.P., respectively, and by a grant from the Natural Science and Engineering Research Council of Canada to M.-A.L.

We are indebted to James S. Haudenshield for his expert technical assistance with the DNA base composition determinations and DNA hybridization experiment.

\section{REFERENCES}

1. Ahearn, D. G., S. P. Meyers, and R. A. Nichols. 1968. Extracellular proteases of yeasts and yeast-like fungi. Appl. Microbiol. 16:13701374.

2. Barker, J. S. F., P. D. East, H. J. Phaff, and M. Miranda. 1984. The ecology of the yeast flora in necrotic opuntia cacti and of associated Drosophila in Australia. Microb. Ecol. 10:379-399.

3. Barnett, J. A., R. W. Payne, and D. Yarrow. 1990. Yeasts, characterization and identification, 2nd ed. Cambridge University Press, Cambridge.

4. Fogleman, J. C., and W. T. Starmer. 1985. Analysis of the community structure of yeasts associated with the decaying stems of cactus. III. Stenocereus thurberi. Microb. Ecol. 11:165-173.

5. Holzschu, D. L., H. L. Presley, M. Miranda, and H. J. Phaff. 1979. Identification of Candida lusitaniae as an opportunistic yeast in humans. J. Clin. Microbiol. 10:202-205.

6. Lachance, M. A., W. T. Starmer, and H. J. Phaff. 1988. Identification of yeasts found in decaying cactus tissue. Can. J. Microbiol. 34:1025-1036.

7. Meyer, S. A. 1993. Personal communication.

8. Meyer, S. A., D. G. Ahearn, and D. Yarrow. 1984. Candida Berkhout, p. 585-844. In N. J. W. Kreger-van Rij (ed.), The yeasts: a taxonomic study, 3rd ed. Elsevier Science Publishers B.V., Amsterdam.

9. Ogrydziak, D. M. 1993. Yeast extracellular proteases. Crit. Rev. Biotechnol. 13:1-55.

10. Price, C. W., G. B. Fuson, and H. J. Phaff. 1978. Genome comparison in yeast systematics: delimitation of species within the 
genera Schwanniomyces, Saccharomyces; Debaryomyces, and Pichia. Microbiol. Rev. 42:161-193.

11. Starmer, W. T., H. W. Kircher, and H. J. Phaff. 1980. Evolution and speciation of host plant specific yeasts. Evolution 34:137-146.

12. Starmer, W. T., M. A. Lachance, H. J. Phaff, and W. B. Heed. 1990 The biogeography of yeasts associated with decaying cactus tissue in North America, the Caribbean, and northern Venezuela. Evol. Biol. 24:253-296.

13. Starmer, W. T., and H. J. Phaff. 1983. Analysis of the community structure of yeasts associated with the decaying stems of cactus. II. Opuntia species. Microb. Ecol. 9:247-259.

14. Starmer, W. T., H. J. Phaff, J. M. Bowles, and M. A. Lachance. 1988. Yeasts vectored by insects feeding on decaying saguaro cactus. Southwest. Nat. 33:362-363.

15. Starmer, W. T., H. J. Phaff, M. Miranda, M. W. Miller, and W. B. Heed. 1982. The yeast flora associated with the decaying stems of columnar cacti and Drosophila in North America. Evol. Biol. 14: 269-295.

16. van der Walt, J. P., and D. Yarrow. 1984. Methods for the isolation, maintenance, classification and identification of yeasts, p. 45-104. In N. J. W. Kreger-van Rij (ed.), The yeasts: a taxonomic study, 3rd ed. Elsevier Science Publishers B.V., Amsterdam.

17. Yarrow, D., and S. A. Meyer. 1978. Proposal for amendment of the diagnosis of the genus Candida Berkhout nom. cons. Int. J. Syst. Bacteriol. 28:611-615. 